\title{
Despre viitorul profesiilor juridice, în contextul principalelor provocări ale următoarelor două decenii
}

\author{
Prof. univ. dr. Valerian Cioclei \\ Facultatea de Drept, universitatea din București \\ Avocat, partener of counsel ZRVP
}

\begin{abstract}
Rezumat: Articolul își propune să analizeze impactul pe care îl pot avea asupra viitorului profesiilor juridice, patru dintre principalele provocări ale lumii contemporane. Deși între toate cele patru provocări există multiple conexiuni, ele au fost grupate în două perechi, în interiorul cărora legăturile sunt mai clare: pandemia și post-adevărul (I), respectiv ingineria genetică și inteligența artificială (II).
\end{abstract}

Cuvinte cheie: pandemie, post-adevăr, ingineria genetică, inteligența artificială, digitalizare, justiţie on-line, social media, tehnologia informației, biotehnologie, robojudecători, robolegiuitori.

\section{On the future of legal professions in the context of the main challenges of the next two decades}

\begin{abstract}
The paper aims to analyse the impact which four of the main challenges of contemporary world may have on the future of legal professions. Although, among the four challenges there are multiple connections, they were grouped into two categories, within which the liens are clear: the pandemic and the post-truth (I) and the genetic engineering and artificial intelligence (II).
\end{abstract}

Key words: pandemic, post-truth, genetic engineering, artificial intelligence, digitalization, online justice, social media, technology of information, biotechnology, robojuges, robolegislators

Este probabil ca următoarele două decenii să fie determinante pentru evoluția societăţii umane. Există câteva provocări majore cărora omenirea va trebui să le facă față în această perioadă. Ele se vor resimți în toate domeniile vieții sociale: relații interumane în general, valori morale, sănătate, cultură, educație, economie, finanțe, etc. Justiția și profesiile juridice nu vor fi nici ele la adăpost. Dintre multiplele provocări preocupante pentru lumea contemporană am identificat un număr de patru, care, în opinia mea, vor avea un impact important asupra „mediului juridic”, în următorii douăzeci de ani. O parte dintre aceste provocări mi-au atras atenția de mai multă vreme, pe altele le-am identificat de curând, forțat de împrejurări mai recente. Deși între toate cele patru provocări există multiple conexiuni, leam grupat în două perechi, în interiorul cărora legăturile sunt mai clare. Voi începe cu cele „mai noi”, respectiv, pandemia și post-adevărul (I), și voi continua cu cele „mai vechi”, respectiv, ingineria genetică și inteligența artificială (II). Evident că în cele ce urmează nu îmi propun o analiză de detaliu ci, pur și simplu, sugerez câteva teme de reflecție.

\section{Pandemia și post-adevărul}

Deși sunt două provocări distincte, am ales să le tratez împreună deoarece ele „se leagă" mai mult decât s-ar putea crede la prima vedere. Pandemia, ca orice pericol colectiv major, naște o ,teamă colectivă”. Orice teamă colectivă are nevoie de o poveste, de o ficțiune. Când povestea potrivită apare și este însușită de colectivitate, ca și când ar fi adevărată, ne 
aflăm în prezența post-adevărului. Așa cum pandemia poate fi considerată ,,apogeul planetar al epidemiei”, post-adevărul poate fi privit ca un ,apogeu planetar al fake news- ului”. Este important așadar să nu pierdem din vedere că atât pandemia (a) cât și post-adevărul (b) reprezintă două fenomene cu caracter global și ele nu pot fi înțelese decât în această dimensiune.

a) Pandemia generată de SARS-CoV-2 este, la momentul la care scriu aceste rânduri, în ,plină desfășurare”. Reprezentanții OMS au declarat recent că aceasta nu se va încheia prea curând ${ }^{1}$. Dar și atunci când se va încheia, nimic nu garantează că ea nu se va reîntoarce. Dacă se va descoperi un vaccin eficace, el ar putea fi depășit de evoluția virusului, de mutațiile pe care acesta le poate suferi. Dacă acest virus, în toate formele lui, va putea fi controlat printr-un vaccin, un virus nou, la fel de periculos ar putea să apară oricând. Este din ce în ce mai evident că omenirea trăiește cu această „sabie a lui Damocles” deasupra capului: posibilitatea ca, în viitor, civilizația umană să piară în urma unui virus de nestăpânit pare, la acest moment, cel puțin egală cu posibilitatea de a pieri în urma unui cataclism nuclear sau ecologic. Din această perspectivă, lumea în general, dar și „lumea juridică” în particular, trebuie să se adapteze la situațiile generate de o pandemie. Experiența recentă ne-a demonstrat că, într-o situație de acest gen, toate ramurile juridice suferă transformări esențiale. Ceea ce s-a întâmplat în domeniul penal, unde s-a impus o reacție rapidă la modificările survenite la nivelul fenomenului criminal, este un exemplu sugestiv, la care m-am referit într-un articol anterior $^{2}$. Au apărut însă reglementări substanţiale noi și în alte domenii, au fost adoptate norme noi în privința derulării proceselor, practica judiciară s-a confruntat cu probleme inedite $^{3}$. Sunt semne clare că multe dintre reglementările nou apărute nu vor rămâne ,de conjunctură” ci ele se vor permanentiza, că va fi nevoie și de alte norme substanțiale și procedurale pentru a acoperi noi realități și relații sociale ce se creează sub ochii noștri. Este foarte posibil, spre exemplu, ca o nouă ramură de drept referitoare la virusuri să își facă apariția (drept viral i-am putea spune). În contextul creat, precum și în cel ce se prefigurează, profesiile juridice trebuie să dovedească o capacitate deosebită de adaptare la schimbările legislative. Pe lângă asimilarea rapidă a noilor reglementări, juriștii în general, dar mai ales avocații și magistrații, au fost nevoiţi să se adapteze la o nouă „logistică” în desfășurarea activității. Astfel, spre exemplu, starea de pandemie a pus în lumină necesitatea digitalizării activităților instanțelor de judecată. „, Dintre soluțiile de digitalizare implementate până în prezent de instanțele judecătorești din România trebuie remarcate următoarele: (i) Accesul online la dosare (...) (ii) Comunicarea prin mijloace informatice a unor acte de procedură (...) (iii) Facilitarea programărilor on-line (...) (iv) Evidența on-line, în timp real, a ședințelor de

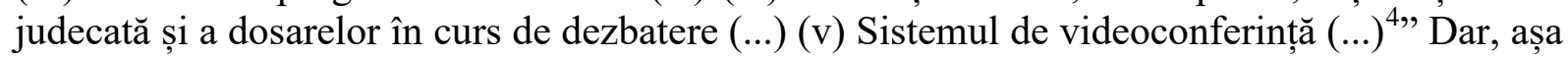
cum s-a afirmat în doctrină, aceste soluții nu reprezintă decât „un pas spre justiția on-line”, care va aduce cu sine, printre altele, , reducerea numărului de litigii care vor ajunge în faţa judecătorului, reducerea cheltuielilor cu sediile și personalul administrativ al instanțelor de judecată, cu hârtia și citarea părților (...)" ${ }^{\prime 5}$. Într-o ,traducere liberă”, migrarea spre o justiție on-line va antrena o diminuare a numărului celor care participă la derularea procedurilor judiciare, fie ei magistrați, avocaţi, consilieri juridici, grefieri. Altfel spus, este posibil ca „piaţa muncii” în domeniul profesiilor juridice să cunoască o restrângere treptată. În plus,

\footnotetext{
1 A se vedea, spre exemplu: https://www.formaremedicala.ro/oms-estimeaza-ca-pandemia-covid-19-va-fi-delunga-durata/

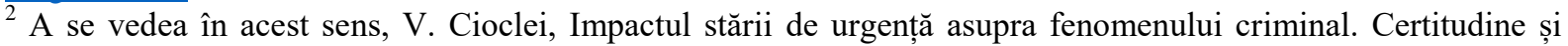
probabilitate, disponibil la: https://drept.unibuc.ro/dyn_img/aubd/Impactul\%20starii\%20de\%20urgenta.pdf

${ }_{3}^{3}$ Pentru o imagine relevantă asupra problemelor cu care s-au confruntat diferitele ramuri de drept, a se vedea lucrarea colectivă: Probleme şi soluții legale privind criza COVID - 19, Ed. C.H. Beck 2020.

${ }^{4}$ I. Militaru, C.V. Iuga, Justiția civilă la distanță. Soluții de digitalizare, în Probleme și soluții legale privind criza COVID - 19, op. cit. p. 227.

${ }^{5}$ Idem, p. 241.
} 
„activitățile judiciare on-line” vor necesita creșterea nivelului de pregătire în domeniul tehnologiei informației, pentru toți profesioniștii dreptului. Rezumând: mai puțini juriști, mai adaptabili la schimbările legislative, mai performanți în domeniul I.T.

b) Post-adevărul reprezintă un concept controversat sau chiar negat de unii autori. Aceste viziuni diferite nu au relevanță în prezentul context deoarece noțiunea va fi întrebuințată ca ,instrument de lucru” adiacent. Din această perspectivă, mă voi referi la postadevăr în sensul de ficțiune (minciună) care este prezentată și repetată în așa fel încât ajunge să fie considerată realitate (adevăr) de un număr foarte mare de persoane. Aparent, postadevărul este specific epocii actuale și are exclusiv valenţe negative. „În realitate, oamenii au trăit dintotdeauna în epoca post-adevărului. Homo sapiens este o specie post-adevăr, a cărei putere depinde de crearea și acceptarea unor ficțiuni. Încă din Epoca Pietrei, rolul miturilor autoconsolidate a fost acela de a uni colectivități umane (...) Atâta vreme cât toată lumea crede în aceleași ficțiuni, cu toții ne supunem acelorași legi și, prin urmare, putem coopera în mod eficient" . Problema nu este așadar acceptarea ficțiunii ca adevăr, în sine, care pare a fi o tendință umană adânc înrădăcinată ci, exploatarea acestei tendințe umane în scopuri malefice. Istoria omenirii este plină de astfel de exemple: „, Pe 29 august 1255, trupul unui băiat englez de nouă ani, pe nume Hugh, a fost găsit într-un puț din orașul Lincoln. Chiar și fără Facebook și Twitter, au început să circule rapid zvonuri că Hugh ar fi fost ucis de evreii din partea locului în cadrul unui ritual. Povestea era înflorită de fiecare dată când era reluată, iar unul dintre cei mai vestiți cronicari englezi ai vremii - Matthew Paris - a oferit o descriere amănunțită și sângeroasă a modului în care câțiva evrei de seamă de pe cuprinsul Angliei s-au adunat la Lincoln ca să-1 îngrașe, să-1 tortureze și, într-un final, să-1 răstignească pe copilul răpit. Nouăsprezece evrei au fost judecați și executați pentru așa-zisa crimă. Acuzații similare de omor ritualic la adresa evreilor au început să curgă și în alte orașe englezești, ducând la o serie de pogromuri în care au fost masacrate comunități întregi. În cele din urmă, în 1290, toată populația evreiască a fost expulzată din Anglia". 7 În acest caz, teama faţă de presupuse ritualuri ucigașe a fost liantul post-adevărului. După cum știm, la alte proporții, istoria s-a repetat sute de ani mai târziu, iar teama inițială, alimentată cu noi temeri, legate, spre exemplu, de puritatea rasei, au făcut posibil Holocaustul. De această dată, manipularea a fost metodică, profesionistă: „Joseph Goebbels, maestrul propagandei naziste și poate cel mai priceput expert media al epocii moderne, ar fi explicat succint în ce constă metoda sa, afirmând că o minciună spusă o dată rămâne minciună, dar o minciună spusă de o mie de ori devine adevăr. În Mein Kampf, Hitler scria: Cea mai strălucită tehnică propagandistică nu va avea niciun succes dacă nu se ține cont în permanență de un principiu fundamental-trebuie să se limiteze la un număr mic de elemente și să le repete la nesfârșit" ${ }^{\prime}$. Aceste exemple susțin o afirmație pe care am făcut-o mai sus, respectiv faptul că orice teamă colectivă ,,are nevoie" de o poveste. Altfel spus, teama este terenul cel mai propice pentru a semăna știrile false, pentru a cultiva post-adevărul.

Dar omenirea a avut dintotdeauna temeri: de zei, de întuneric, de alt trib, de altă națiune etc. În prezent, teama globală principală este pandemia, despre care am discutat anterior, dar alături de ea, în diferite comunități, mai mari sau mai mici, „conviețuiesc” multe alte temeri colective. Terenul pentru cultivarea post-adevărului este, deci, și azi propice. Marea diferență față de trecut este faptul că, în zilele noastre, uneltele pentru cultivarea postadevărului au devenit implacabile. Mă refer aici la media de socializare online („social media"), în general, și, în special, la rețelele de socializare (social networks). Cu ajutorul acestora, printr-un simplu click, o știre falsă poate ajunge într-o secundă la milioane de

\footnotetext{
${ }^{6}$ Y.N. Harari, 21 de lecții pentru secolul XXI, Ed. Polirom, 2018, p. 235.

${ }^{7}$ Idem p. 237.

${ }^{8}$ Idem p. 238.
} 
oameni și ea poate fi repetată de „o mie de ori”, astfel încât să devină adevăr. În acest context, este și va fi din ce în ce mai greu să distingem adevărul de minciună.

Profesiile juridice nu trăiesc într-un ,glob de sticlă”, ele sunt, la rândul lor, expuse știrilor false și post-adevărului pe care acestea îl pot crea. Lumea este în căutarea unor noi paradigme sociale, a unor noi ideologii. $\mathrm{Nu}$ știm cum vor arăta acestea și ce rol vor atribui profesiilor juridice. Știm însă că unele ideologii extremiste și regimurile pe care acestea le-au creat s-au bazat pe post-adevăr, iar acest fapt trebuie să reprezinte întotdeauna un semnal de alarmă: și în regimul nazist, bazat cum arătam mai sus pe un post-adevăr, profesiile juridice au funcționat...

Dar până la un viitor scenariu catastrofal general, pe care ni-l putem imagina pornind de la realități istorice, putem privi la realitățile contemporane de „mai mică anvergură” pentru că, așa cum se știe, uneori, diavolul (post-adevărul) se poate ascunde în „detalii”. Să luăm așadar, spre exemplificare, două ipoteze actuale, în care, perpetuarea știrilor false poate influența profesiile juridice, activitatea acestora.

O primă ipoteză este aceea în care post-adevărul stă la baza legiferării. Mecanismul este relativ simplu: se creează o imagine falsă asupra unor realităţi sociale (un post-adevăr), care să impună o anumită conduită normativă, ce se va traduce prin aplicarea practică în satisfacerea unor interese individuale sau de grup. Am dat recent câteva exemple din domeniul penal, analizând politica penală populistă pe care o defineam ca fiind: „Exacerbarea sentimentului de insecuritate publică, prin toate mijloacele, cu precădere a celor de informare în masă, urmată de propunerea și adoptarea unor soluții „salvatoare”, precum introducerea de noi incriminări sau sporirea pedepselor, în scopul de a obține voturi sau de a „fideliza" electoratul". ${ }^{9}$ Domeniul dreptului penal nu este însă singurul vizat, situații de acest gen au existat în trecutul mai îndepărtat sau mai apropiat în toate domeniile de legiferare. Profesioniștii dreptului nu trebuie să cadă în astfel de capcane. Ei trebuie să aibă totdeauna informația corectă și să împiedice acest gen de reglementare. O pot face în mod direct, atunci când sunt implicați într-un fel sau altul în procesul legislativ, sau indirect, fie prin reprezentanții profesiilor, fie în mod individual prin exprimarea unor puncte de vedere știinţific argumentate (în articole, conferințe, etc.)

O a doua ipoteză este aceea în care post-adevărul stă la baza unor decizii judiciare. Voi lua tot un exemplu din domeniul dreptului penal pentru că îmi este mai „la îndemână”. Este de notorietate faptul că, în ultimii ani, cu ,ajutorul” presei și al „social media”, s-a inoculat în opinia publică (implicit în rândul magistraților) convingerea că: fie, întreaga clasă politică este coruptă, fie o parte a clasei politice este coruptă, fie, nominal, oamenii politici X, Y, Z etc. sunt corupți. Evident, pentru a avea și elementul corelativ necesar actelor de corupție (spre exemplu dare de mită-luare de mită), anatema a căzut și asupra oamenilor de afaceri, în general, sau asupra unei categorii de oameni de afaceri, ori asupra unor oameni de afaceri indicați nominal. Aceste convingeri inoculate opiniei publice reprezintă în mod evident postadevăruri, câtă vreme, există chiar și o singură persoană din categoriile indicate sau dintre cele nominalizate care nu este coruptă, adică, nu a fost condamnată printr-o hotărâre definitivă, pentru o infracțiune de corupție. Este iarăși de notorietate că, în paralel, s-a derulat grotescul „,spectacol al cătușelor”, care a creat un alt post-adevăr, respectiv convingerea că toate persoanele încătușate sunt vinovate, indiferent de soluția ce urma să se dea în cauză, care nu mai interesa opinia publică. Turnura ulterioară a unor astfel de cauze, respectiv, adoptarea unor soluții de clasare la nivelul parchetelor, sau achitările definitive pronunțate de instanțele de judecată, confirmă faptul că organele judiciare, cel puțin până la un punct, au fost victimele unei specii grave de post-adevăr, pe care am putea-o numi post-adevăr judiciar. Am folosit cu bună știință noțiunea de victimă pentru că am luat în calcul ipoteza în care organele

V. Cioclei, 3P, un „virus” reactivat, care amenință sănătatea justiției penale, disponibil la: http://www.bizlawyer.ro/stiri/interviuri-opinii/3p-un-virus-reactivat-care-ameninta-sanatatea-justitiei-penale 
judiciare au lucrat cu bună credință. Cealaltă ipoteză, a relei credințe, aflată în zona cercetării abuzive sau a altor infracțiuni comise de magistrați nu a fost avută în vedere deoarece, deocamdată, deși există cauze pe rol, din câte știu, nu există soluții de condamnare definitive, astfel încât, nu vreau să fiu eu însumi sursa unui eventual post-adevăr. Pentru a nu se lăsa influențați sau chiar manipulați prin procedee de genul celor expuse mai sus, juriștii în general, și în particular (în ipoteza dată) magistrații, trebuie să fie extrem de vigilenți și să nu accepte ,adevăruri gata preparate”.

În mod evident, pot fi identificate și alte ipoteze în care profesiile juridice se confruntă cu această provocare reprezentată de post-adevăr. Ideea nu a fost să alcătuiesc un inventar al acestora ci, să atrag atenția că problema există și în acest domeniu, așa cum există pretutindeni în societate. Sunt de așteptat reglementări noi cu privire la furnizarea și veridicitatea informațiilor, poate o nouă ramură de drept se va consolida. Până atunci, trebuie să conștientizăm că provocarea post-adevărului este una cât se poate de serioasă și trebuie să o înfruntăm cu uneltele pe care le avem la îndemână. „Prin urmare, în loc să acceptăm știrile false ca pe o normă, ar trebui să recunoaștem că reprezintă o problemă mult mai dificilă decât avem tendința să credem și ar trebui să ne străduim și mai mult să distingem realitatea de ficțiune (...) Este responsabilitatea noastră, a tuturor, să investim timp și efort pentru a ne scoate la iveală prejudecățile și a ne verifica sursele de informare"10. Mutatis mutandis, aceeași responsabilitate le revine și juriștilor. Mai trebuie adăugat că, în domeniul dreptului, pentru a avea abilitatea de a verifica sursele de informare și, în final, de a distinge între adevăr și ficțiune, este nevoie de o cultură juridică solidă, care este imposibil de dobândit fără o cultură generală cât mai consistentă și, care, la rândul ei, nu se poate construi atunci când te limitezi la informațiile dobândite prin internet. Prin urmare, este previzibil ca profilul juristului performant al următoarelor decenii să conțină și această calitate: o cultură juridică solidă având la bază o cultură generală consistentă, ,impermeabilă” la post-adevăr.

\section{Ingineria genetică și Inteligența artificială}

După ce în prima parte am examinat perechea formată din pandemie și post-adevăr, să trecem în continuare la „tandemul”: Inginerie genetică-Inteligență artificială. Având în vedere că sunt două sintagme ce nu intră în ,repertoriul” uzual al juristului cred că este potrivit să fac scurte precizări prealabile cu privire la sensul pe care îl voi da acestora. Astfel, conștient de faptul că, în lumea științifică, cele două sintagme pot avea înțelesuri sensibil diferite, de la un autor la altul, nu am fost preocupat de găsirea unor definiții cât mai exacte din punct de vedere tehnic ci, am ales acele semnificații uzuale, cu un grad ridicat de generalitate, mai adecvate unei dezbateri juridice.

Din perspectiva anunțată, sintagma inginerie genetică va fi utilizată cu sensul de: „metodă prin care se modifică genomul natural al unui organism prin adăugarea de fragmente noi de ADN. În acest fel se creează organisme reprogramate genetic al căror genom se transmite stabil la sute de generații viitoare și care nu rezultă în urma procesului de selecție naturală" ${ }^{\prime 1}$. Mai precizez că ingineria genetică este considerată a fi elementul de bază al biotehnologiei moderne ${ }^{12}$, ceea ce înseamnă că referirile la această din urmă noțiune pot fi valabile și cu privire la cea dintâi, prin relația de la întreg la parte.

Din aceeași perspectivă, prin Inteligență Artificială (IA) se va înțelege „,capacitatea mașinilor sau a computerelor de a îndeplini atribuții și sarcini asociate în mod obișnuit cu inteligența umană ${ }^{\prime \prime 13}$. Este important de adăugat că IA reprezintă una dintre axele strategice

\footnotetext{
${ }^{10}$ Y.N. Harari, op. cit. p. 244.

${ }^{11}$ https://www.stiintaonline.ro/ce-este-ingineria-genetica/

12 https://www.viata-medicala.ro/na/p-pastila-de-biotehnologie-by-amgen-ingineria-genetica-elementul-de-bazaal-biotehnologiei-moderne-11575

${ }^{13}$ https://gotech.world/inteligenta-artificiala-definitie-tipuri-de-ai-cum-invata-si-ce-aplicatii-are/
} 
de cercetare din domeniul tehnologiei informației (IT) ${ }^{14}$, altfel spus, este un subdomeniu al acesteia. Prin urmare, referirile la IT pot fi valabile și pentru IA, prin relația de la întreg la parte.

$\mathrm{Cu}$ semnificațiile anterior enunțate, cele două provocări asupra cărora mă voi opri în cele ce urmează, Ingineria genetică și Inteligența artificială au, în pofida aparențelor, mai multe puncte de legătură. Există convingerea că, ,în tandem”, aceste două provocări (sau domeniile mai largi din care fac parte) vor aduce în viitorul apropiat modificări economice și sociale pe care nici măcar nu le putem bănui. Dar asta nu este totul. „Şi mai important, cele două revoluții, a tehnologiei informației și a biotehnologiei, ar putea restructura nu numai economii și societăţi, ci și corpul și mintea noastră. În trecut, noi, oamenii, am învățat să controlăm lumea exterioară, dar am avut un control destul de limitat asupra lumii noastre interioare. Știam să construim un dig și să împiedicăm ieșirea din albie a unui râu, dar nu știam să oprim îmbătrânirea corpului. Știam să proiectăm un sistem de irigații, dar habar nu aveam să proiectăm un creier. Dacă țânțarii ne bâzâiau la ureche și ne tulburau somnul, știam cum să ucidem țânțarii; dar, dacă un gând nu ne dădea pace și nu ne lăsa să dormim noaptea, cei mai mulți dintre noi nu știau cum să omoare gândul. Revoluțiile din biotehnologie și tehnologia informației ne vor oferi controlul asupra lumii noastre interioare și ne vor permite să concepem și să creăm viață. Vom învăța să proiectăm creiere, să prelungim viața și să ucidem gânduri după bunul nostru plac. Nimeni nu știe care vor fi consecințele"15. Această imagine a viitorului, deosebit de plastică, desprinsă parcă dintr-un roman S.F., devine din ce în ce mai credibilă în ochii multor savanți. Sigur, așa cum spunea autorul citat, nimeni nu poate să prevadă consecințele unei astfel de evoluții, mai ales pe termen lung. Suntem însă obligați să încercăm să anticipăm, cel puțin pe termen scurt (următorii douăzeci de ani), cum anume vor fi influențate profesiile juridice de dezvoltarea rapidă a cunoștințelor și practicilor în cele două domenii. Ca și în cazul primei perechi analizate (pandemie - post-adevăr), trebuie să ținem cont că și componentele acestei a doua perechi de provocări, ingineria genetică (a) și inteligența artificială (b) au un pronunțat caracter global și ele nu pot fi înțelese decât în această dimensiune.

a) Ingineria genetică în sensul precizat anterior are o istorie relativ scurtă, dacă ne raportăm la istoria științei, și infinitezimal de scurtă, dacă ne raportăm la istoria genei în sine, care se confundă cu cea a ,supei primitive, despre care biologii și chimiștii cred că ar fi constituit oceanul planetar acum trei până la patru miliarde de ani" ${ }^{\prime \prime}$.

În acea „supă”, la un moment dat, din pură întâmplare, s-a format „,replicatorul”, „o moleculă cu totul remarcabilă (...) care avea extraordinara proprietate de a fi capabilă să creeze propriile sale copii" ${ }^{\prime 17}$. Cum echivalentul modern al primului replicator este reprezentat de moleculele de $\mathrm{ADN}^{18}$, iar gena, înțeleasă ca unitate moleculară a eredității în organismele vii, este compusă „dintr-o secvență de $\mathrm{ADN}^{\prime 19}$, se poate afirma că gena își are originea în supa primitivă sus amintită. Pornite acum patru miliarde de ani, unele dintre acele molecule auto-copiatoare au ajuns în zilele noastre. Replicatorii care au supraviețit au fost aceia care și-au construit maşini de supraviețuire, în care să trăiască: oamenii, animalele, plantele, bacteriile și virusurile ${ }^{20}$. „Au străbătut o cale lungă acești replicatori. Acum merg mai departe

\footnotetext{
${ }^{14}$ https://www.etsmtl.ca/Recherche/Recherche-et-innovation/Technologies-information-et-communications

${ }^{15}$ Y.N. Harari, op. cit., p. 20.

${ }^{16}$ R. Dawkins, Gena egoistă, Ed. Publica, 2013, p. 55.

${ }^{17}$ Idem p. 56.

${ }^{18}$ Idem p. 57.

${ }^{19}$ S. Mukherjee, Gena. O istorie fascinantă, Ed. ALL, 2018, p. 470. Mai extins: „Genă = Unitate a moștenirii ereditare, compusă în mod normal dintr-o secvență de ADN care codifică o proteină sau un lanț de ARN (în cazuri speciale, genele pot fi transportate sub formă de ARN).

${ }^{20}$ R. Dawkins, p. 62 și 65.
} 
sub numele de gene, iar noi suntem mașinile lor de supraviețuire" ${ }^{21}$. De unde atâta vitalitate într-o „,biată” moleculă? Caracterul său ,egoist” pare a fi cheia succesului. „, Ce este gena egoistă? Nu este numai o porțiune fizică distinctă de ADN. Ca și în supa primitivă, ea reprezintă toate replicile unei anumite porţiuni de $\mathrm{ADN}$, răspândite de-a lungul și de-a latul lumii. (...) ce încearcă să facă o genă egoistă? Ei bine, încearcă să se înmulțească în fondul genetic. În esență, ea face acest lucru dând ajutor la programarea corpurilor în care se găsește,

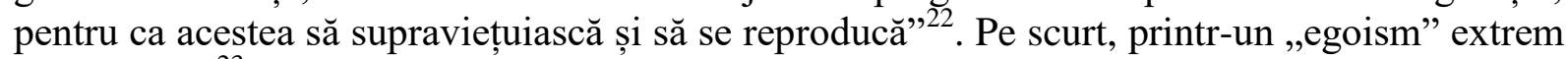
de sofisticat ${ }^{23}$, unele gene se perpetuează în mod implacabil în lumea vie, fiind stăpânele propriului lor destin, dar și al mașinilor în care ,au ales” să supraviețuiască.

În cazul ființei umane, această ,tiranie” a genei este atenuată de influența echivalentului ei cultural: mema. „Transmiterea culturală este analoagă cu transmiterea genetică prin aceea că, deși în fond conservatoare, poate să dea naștere unei forme de evoluție". ${ }^{24}$ Mema, ca replicator, este acea creație culturală (în sens foarte larg: de la credință la știință, trecând prin artă sau modă) care are capacitatea de a se propaga, de a se transmite

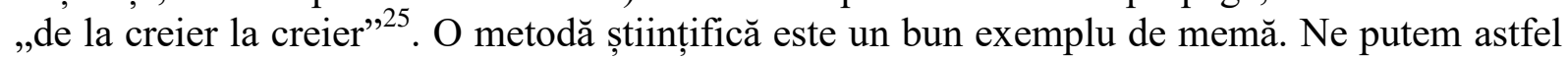
reîntoarce la subiectul iniţial, ingineria genetică, „o memă ce se ocupă de genă”.

Metoda reprezentată de ingineria genetică este o creaţie colectivă la care s-a ajuns treptat, prin contribuția mai multor generații de savanți în domeniul biotehnologiei. Progresul înregistrat în înțelegerea și manipularea genelor a dus, inevitabil, la ideea manipulării genomului (totalitatea informației genetice din organism) ceea ce schimbă total „filosofia” intervenției genetice, mai ales dacă ne gândim la aplicarea acesteia în cazul genomului uman: „Manipularea genelor înseamnă un lucru, dar manipularea genomurilor înseamnă cu totul altceva. În anii 80-90 ai secolului trecut, tehnologia de secvențiere a ADN-ului și de clonare genetică a permis oamenilor de știință să înțeleagă și să manipuleze genele și să controleze astfel biologia celulelor cu o dexteritate extraordinară. Dar manipularea genomurilor în contextul lor nativ, mai ales în celulele embrionare sau germinale, deschide poarta către o tehnologie mult mai puternică. Ceea ce este în joc nu mai este o celulă, ci un organism-noi înșine" ${ }^{\text {26 }}$. Sunt oameni de știință care consideră că din punct de vedere tehnic există în prezent toate ,ingredientele" necesare pentru a ajunge, ,aproape fără efort, la oameni modificaţi genetic" $^{27}$. Singura reținere în angajarea într-o astfel de ,,aventură" o au tot oamenii de știință care au înțeles că nu pot anticipa în întregime consecințele ei biologice și morale. Imaginându-ne o lume în care tehnologia deja existentă ar fi aplicată în practică am putea avea următoarea descriere: „, Este o lume locuită de previețuitori şi post-oameni: femei și bărbați care au fost testați pentru vulnerabilităţi genetice sau au fost creaţi cu anumite înclinații genetice modificate. S-ar putea ca bolile să dispară rând pe rând, dar tot la fel ar putea să dispară și identitatea. S-ar putea să fie mai puțină supărare, dar și tandrețea să fie la fel de puțină. Putem șterge traumele, dar la fel de bine putem șterge și istoria. Mutanții ar putea fi eliminați, dar eliminată va fi și variația umană. Infirmitățile ar putea să dispară, dar la fel și vulnerabilitatea. Hazardul va putea fi diminuat, dar în mod inevitabil va fi diminuată și posibilitatea de alegere"28. Dar, oricâte griji ne-am face și oricât de conștienți am fi de pericolele ce ne pândesc, procesul este ireversibil. Orice descoperire științifică aplicabilă în

\footnotetext{
${ }^{21}$ Idem, p. 63.

${ }^{22}$ Idem, p. 167.

${ }^{23}$ Pentru a înțelege corect „epitetul” egoist asociat genei, ar trebui consultată întreaga lucrare a lui Dawkins citată anterior.

${ }^{24}$ R. Dawkins, p. 323.

${ }^{25}$ Idem, p. 328.

${ }^{26}$ S. Mukherjee, op. cit. p. 448.

${ }^{27}$ Idem, p. 449. Nu am considerat util în acest cadru să intru în detalii dar, la pagina citată, autorul indică etapele necesare pentru modificarea genomului uman, toate posibile cu ajutorul tehnologiei actuale.

${ }^{28}$ Idem, p. 463.
} 
practică, va fi aplicată, mai devreme sau mai târziu (povestea bombei atomice este doar un exemplu în acest sens). De fapt, în realitate, nici nu știm dacă primul om ,„post-genomic” nu sa născut deja ${ }^{29}$.

$\mathrm{Nu}$ am luat în discuție problemele legate de impactul actual al biotehnologiei, în general, sau al geneticii medicale, în particular, asupra Dreptului, deoarece aceste probleme, deja extrem de complicate, sunt pe larg dezbătute în doctrină. Am trecut în mod intenţionat direct la „nivelul următor”- modificarea genomului uman - pentru că este exemplul cel mai șocant al schimbărilor ce vor urma. În paranteză fie spus, dacă cineva se gândește la art. 13 din Convenția de la Oviedo ${ }^{30}$, este pe o pistă falsă. Eu mă refer la momentul în care toate actele normative interne și internaționale care interzic „modificări în genomul descendenților” sunt istorie. Aceasta se poate întâmpla, fie printr-o schimbare de paradigmă juridică în domeniu, la nivel internațional, fie prin constatarea unei realități post-factum ( se descoperă, pur și simplu, la un moment dat, că un număr mai mic ori mai mare de persoane au suferit deja modificări genomice transmisibile). Ambele ipoteze sunt posibile, având în vedere că: , Dorinţa de a modifica genomul embrionului uman s-a transformat într-un fel de cursă a înarmărilor intercontinentală"’31.

Este evident că dezvoltarea aplicațiilor din domeniul biotehnologiei, în general, și al ingineriei genetice, în particular, vor avea un impact important și asupra profesiilor juridice. Am convingerea că multe dintre problemele ,punctuale” ce se vor ivi sunt, în acest moment, imposibil de anticipat. În același timp, cred că este rezonabil să apreciem că, în linii generale, impactul se va manifesta pe cele două mari paliere ale „tărâmului” juridic: activitatea de legiferare și cea de aplicare a legii. În ambele activități va fi nevoie de oameni ai dreptului care să priceapă fenomenul, să aibă o reprezentare cât mai corectă a acestuia. Ei vor trebui să iasă puțin din „bula juridică” în care se închid, de regulă, și să încerce să-și lărgească orizontul cunoașterii și spre acest domeniu al geneticii. Sigur, juriștii vor avea sprijinul specialiștilor dar, ca să înțeleagă „limbajul” acestora, vor avea nevoie, cel puțin, de un set minim de cunoștințe în domeniu. $\mathrm{Nu}$ va fi simplu pentru cei care, înainte de intrarea la Facultatea de Drept, au auzit doar povestea coastei lui Adam, fără să audă și povestea lui Darwin dar, dacă există dorința de cunoaștere, lucrurile se pot îndrepta. Și ele trebuie să se îndrepte, pentru că dacă nu înțelegem cine suntem și cum am evoluat că să ajungem ce suntem azi, sigur nu vom ști cum să construim și să aplicăm legi pentru post-oamenii de mâine, despre care vorbea un autor citat mai sus.

b) Inteligența artificială (nebiologică), în sensul amintit mai sus, există de multă vreme printre noi în computere, roboți, mașini. IA este în spatele: aplicațiilor cu care jucăm șah, go, sau alte jocuri; recomandărilor pe care ni le fac magazinele online având în vedere cumpărăturile anterioare; postărilor și reclamelor care ne apar pe rețelele de socializare, după analiza preferințelor noastre; autovehiculelor fără șofer etc. Inteligența artificială a intrat deja și în domeniul justiţiei: în Estonia, cele mai simple procese civile, cu miză de sub 6.400 de euro, sunt decise de un sistem de inteligență artificială. Anual, 30.000 de astfel de spețe sunt

\footnotetext{
${ }^{29}$ În acest sens a se vedea Idem, p. 452.

${ }^{30}$ Art. 13. „Intervenții asupra genomului uman. O intervenție destinată să modifice genomul uman nu se poate face decât din motive preventive, diagnostice sau terapeutice și numai dacă nu are drept scop introducerea unei modificări în genomul descendenților”. Convenția Europeană din 4 aprilie 1997 pentru protecția drepturilor omului și a demnității ființei umane față de aplicațiile biologiei și medicinei, Convenția privind drepturile omului și biomedicina M.Of. nr. 103 din 28 februarie 2001, vezi: http://legislatie.just.ro/Public/DetaliiDocument/27007

${ }^{31}$ S. Mukherjee, op. cit. p. 452. Autorul face referire la diferența de standarde bioetice dintre savanții occidentali şi cei asiatici şi la temerea celor dintâi că, din această cauză, vor ,pierde startul” în competiţia privind modificarea genomului uman. În acest sens, autorul citează declaraţia sugestivă a unui comentator pe acest subiect:, Dacă nu facem noi acest lucru, îl va face China”.
} 
judecate de un robot cu o interfață umană prealabilă; ${ }^{32}$ in Statele Unite, diferite software-uri sunt utilizate pentru a ,identifica” minorii cu risc de delincvență sau pentru a prezice riscul de recidivă în cazul persoanelor ce urmează a fi eliberate condiţionat (sigur, aceste programe au fost criticate deoarece pot da erori dar, ele există ${ }^{33}$. Pot fi date și alte exemplele de acest gen; în principiu, toate se referă la utilizarea a ceea ce specialiștii numesc inteligență artificială slabă, sau îngustă (limitată). Marea dezbatere actuală în rândul specialiștilor în IA se referă la „,nivelul următor”, respectiv la inteligența artificială generală (IAG), cea care are capacitatea de a îndeplini orice sarcină cognitivă, cel puțin la fel de bine ca oamenii sau, la un moment dat, chiar mai bine. Controversele sunt extrem de aprinse în acest domeniu, iar opiniile variază între ideea că IAG nu poate să apară într-un viitor previzibil și ideea că acest nivel se va atinge în următoarele decenii ${ }^{34}$. Argumentele aduse de diferiții , „combatanți” nu au relevanță în acest context. Ceea ce merită a fi observat este faptul că savanți de prestigiu nu exclud apariția unei inteligențe artificiale de nivel uman în următoarele decenii ${ }^{35}$, precum și faptul că acești oameni de știință, nejuriști, își pun probleme extrem de serioase cu privire la impactul IA asupra elaborării și aplicării legii. Cred că este important să cunoaștem această viziune care vine din afara sistemului juridic deoarece este de presupus că noi, „sclavii” sistemului, avem o abordare subiectivă și inevitabil conservatoare asupra problemei în cauză, deoarece nu ne dorim să fim înlocuiți de roboți. Iată câteva exemple despre cum vede un specialist în IA, impactul acesteia asupra legii și aplicării ei:

În privința procesului legislativ, după cum era de anticipat, se pune chiar problema apariției robolegiuitorului: „, Există un larg consens cu privire la faptul că legile noastre trebuie să evolueze pentru a ține ritmul cu tehnologia. De exemplu, cei doi programatori care au creat viermele ILOVEYOU, provocând pagube de miliarde de dolari, au fost achitați de toate acuzațiile pentru că în Filipine nu existau pe atunci legi în privinţa malware-ului. De când ritmul progresului tehnologic s-a accelerat, legile trebuie actualizate și mai rapid, căci au tendinţa să fie defazate. Angajarea tot mai multor informaticieni experți în învăţământul juridic și în guvernare ar fi probabil o soluție bună. Ar trebui însă oare să apară sisteme de luare a deciziilor bazate pe IA pentru votanți și legiuitori, urmate de robolegiuitori în toată puterea cuvântului” ${ }^{36}$. Autorul nu oferă un răspuns la întrebare dar subliniază, prin diferite exemple, cât de greu va fi de stabilit granița dintre justiție și confidențialitate, dintre protejarea societăţii și protejarea libertăţii personale. $O$, controversă captivantă” este legată chiar de reglementarea cercetării în domeniul IA. Trebuie aceasta încurajată, sau trebuie să i se aducă unele îngrădiri (ceea ce ar duce, exact la aceeași problemă din ingineria genetică: „dacă nu o facem noi, o vor face alții”). În fine, o altă controversă este legată de automobilele care se conduc singure. Se știe că acestea au produs deja accidente și s-a pus problema răspunderii, civile sau penale. În acest context se naște întrebarea: pot avea aceste automobile o asigurare proprie? Dacă da, atunci pot avea și bani sau proprietăţi? „Dacă acorzi maşinilor dreptul la proprietate, le-ai acorda și dreptul de a vota",37?

În privința aplicării legii - ați ghicit - este pusă în discuție apariția robojudecătorilor: ,, Ce îți vine în minte când te gândești la sistemul juridic din țara ta? Termene lungi, costuri ridicate și, uneori, nedreptate - și nu ești singurul. N-ar fi oare minunat dacă primele cuvinte

\footnotetext{
${ }^{32}$ https://www.juridice.ro/643353/estonia-procesele-civile-cu-miza-de-sub-6-400-euro-sunt-rezolvate-derobot.html

${ }^{33}$ A se vedea în acest sens, spre exemplu, https://www.cnetfrance.fr/news/serons-nous-juges-demain-par-desrobots-juges-39896657.htm

${ }^{34}$ În sensul celor de mai sus și pentru mai multe amănunte a se vedea, M. Tegmark, Viața 3.0. Omul în epoca inteligenței artificiale, Ed. Humanitas, 2019, pp. 39-48.

${ }^{35}$ Mă refer la autorul citat anterior, M. Tegmark, fizician, Profesor la Institutul Tehnologic din Massachusetts, dar și la alți oameni de știință la care acesta face trimitere în lucrarea mai sus citată.

${ }^{36}$ M. Tegmark, op. cit. p. 122.

${ }^{37}$ Idem, p. 125.
} 
care ți-ar veni în minte ar fi eficiență și corectitudine? Din moment ce procesul juridic poate fi privit în mod abstract ca un calcul, introducând informații despre dovezi și legi și extrăgând o decizie, unii visează să-1 automatizeze complet cu robojudecători: sisteme IA care aplică neobosit aceleași standarde juridice înalte la orice hotărâre judecătorească, fără a cădea pradă erorilor umane cum sunt părtinirea, oboseala și ignorarea celor mai recente cunoștințe tehnice" 38 . În mod obiectiv, autorul pune în balanță avantajele și dezavantajele unui astfel de sistem. Printre avantaje, se estimează că acesta ar putea garanta o adevărată egalitate în faţa legii, o totală imparțialitate și transparență. În plus: „Robojudecătorii ar putea elimina și preferințele umane accidentale, neintenționate. De pildă un controversat studiu asupra judecătorilor israelieni afirma că aceștia dau verdicte semnificativ mai aspre atunci când le este foame: dacă imediat după micul dejun refuză $35 \%$ din cererile de eliberare condiționată, chiar înainte de prânz ei refuză $85 \% " 39$. Printre neajunsuri se enumeră posibilitatea ca aceste sisteme să aibă bug-uri (erori de programare) sau să fie victimele hackerilor. Mai mult, există pericolul ca soluțiile, deși corecte pe fond, să fie neinteligibile pentru părți. În sfârșit, există riscul unui „subiectivism” statistic: „Ce se întâmplă însă dacă sistemul găsește că recidivismul e corelat statistic cu sexul sau rasa deținutului - ar fi considerat un robojudecător sexist sau rasist care trebuie reprogramat? Un studiu din 2016 susține că software-ul folosit în Statele Unite pentru predicția recidivismului îi defavoriza pe afro-americani și a contribuit la sentințe nedrepte" 40 . Iată doar o parte din multele aspecte controversate legate de subiect. „Acestea sunt aspecte importante care trebuie analizate și discutate pentru a ne asigura că IA rămâne benefică. Nu suntem puși în fața unei hotărâri de tipul totul-sau-nimic în privința robojudecătorilor, ci ar trebui să hotărâm în ce măsură și în ce ritm vrem să folosim IA în sistemul nostru juridic. Vrem ca judecătorii umani să fie ajutaţi de sisteme de decizie bazate pe IA, la fel ca medicii de mâine? Vrem să mergem mai departe și să avem decizii ale robojudecătorilor, iar apelul să fie lăsat în seama judecătorilor umani, sau vrem să mergem până la capăt, dând mașinilor ultimul cuvânt chiar și în cazul pedepsei cu moartea" "41 ? Dar nu numai activitatea magistraţilor riscă ,intruziuni” din partea IA. Juriștii în general sunt „amenințaţi”, inclusiv avocații. Într-un context mai larg, privind meserii ce necesită o bună intuiție, se apreciază că și avocatul poate fi „depășit” de IA: „, Mult lăudata intuiție omenească este în realitate recunoaștere de tipare. Șoferii, bancherii și avocații buni nu au intuiții magice legate de trafic, de investiții sau de negocieri - mai curând, identificând tiparele recurente, observă și încearcă să evite pietonii neatenți, debitorii inepți și escrocii mincinoși. De asemenea, s-a dovedit că algoritmii biochimici ai creierului uman nu sunt câtuși de puțin perfecți (...). Nu e de mirare că până și șoferii, bancherii și avocații buni mai fac uneori greșeli stupide. Asta înseamnă că IA îi poate întrece pe oameni chiar și în privinţa sarcinilor care necesită, chipurile, intuiție (...). IA poate îndeplini mai bine îndeosebi sarcinile care necesită intuiții despre alte persoane. În numeroase domenii de activitate - cum ar fi conducerea unui vehicul pe o stradă plină de pietoni, acordarea unor împrumuturi solicitate de necunoscuți și negocierea unei tranzacții - e nevoie să apreciezi corect emoțiile și dorințele altor persoane (...). Un șofer care anticipă intențiile unui pieton, un bancher care evaluează credibilitatea unui potențial debitor și un avocat care analizează atmosfera de la masa negocierilor nu se bazează pe vrăjitorie. Mai curând, fără ca ei să știe, creierele lor identifică tiparele biochimice analizând expresiile faciale, tonalitățile vocilor, mișcările mâinilor și chiar mirosurile corporale. O IA dotată cu senzori potriviţi ar putea face toate astea cu mult mai multă acuratețe și precizie decât un om"42.

\footnotetext{
${ }^{38}$ Idem, p. 120.

${ }^{39}$ Idem, p. 121.

${ }^{40}$ Idem, p. 122.

${ }^{41}$ Ibidem.

${ }^{42}$ Y.N. Harari, op. cit. p. 34.
} 
Iată cum sunt văzute, „din afară”, multiplele aspecte ale posibilei influențe a IA asupra profesiilor juridice. Firește, așa cum spunea un autor citat mai sus, aceste aspecte trebuie analizate și discutate pentru a ne asigura că IA rămâne benefică. Aș adăuga că aceste aspecte trebuie, și vor fi, negociate. Dar, la „masa” negocierilor trebuie să stea și juriștii, singurii capabili să înțeleagă dreptul, ca fenomen complex al vieții sociale. Or, pentru a sta la o astfel de masă, pe lângă cunoștințele solide legate de propriul domeniu, juriștii trebuie să aibă o reprezentare cât mai corectă despre domeniul general al tehnologiei informației precum și despre cel special al inteligenței artificiale.

Am ,abuzat” în cele de mai sus de citate preluate din lucrările unor reputați oameni de știință și de trimiteri la acele lucrări, pentru a accentua faptul că nu pun în discuție scenarii S.F. Sunt probleme legate de prezentul nostru și de un viitor care este mult mai apropiat decât am fi tentați să credem...

Rezumând și combinând constatările legate de fiecare dintre cele patru provocări examinate am putea încerca să ajungem la câteva concluzii de ordin general: Pandemia ne-a „,̂mpins” deja spre digitalizare și ne „sugerează” un viitor cu mai puțini juriști, mai adaptabili la schimbările legislative, mai performanți în domeniul tehnologiei informației. Inteligenţa artificială va accentua tendința de restrângere a ,pieței de muncă” în domeniul dreptului, iar acest proces va trebui „controlat” de juriști, nu doar mai performanţi în domeniul IT, ci și capabili să înțeleagă avantajele și pericolele IA. Post-adevărul, mai exact lupta contra acestuia, va face ca profilul juristului performant al următoarelor decenii să implice o cultură juridică solidă având la bază o cultură generală consistentă, „impermeabilă” la minciunile construite. Ingineria genetică ne arată că în cadrul acelei culturi generale consistente de care aminteam mai sus, juristul trebuie să ,redescopere” perspectiva evoluționistă, pentru că, dacă nu înțelegem cine suntem și cum am evoluat că să ajungem ce suntem azi, sigur nu vom ști cum să construim și să aplicăm legi pentru „mai complicații” oameni de mâine.

Prin urmare este foarte probabil ca profesiile juridice să necesite reconfigurări importante în ceea ce privește formarea, recrutarea și pregătirea continuă. În același timp, trebuie spus că aceste provocări aduc „la pachet” nu numai „,pericole” ci și oportunități fără precedent. Trebuie să avem în permanență „mintea deschisă” pentru a ne spori capacitatea de adaptare.

În final aș reaminti că provocările în discuție au un pronunțat caracter global și ele nu pot fi înțelese decât în această dimensiune. Din această perspectivă este bine de luat în calcul faptul că schimbările preconizate se vor produce independent de „ritmul plaiului mioritic”. Mai neacademic spus: chiar dacă noi ne vom ,încăpățâna" ca în unele domenii să rămânem în evul mediu, aşa cum internetul a „dat buzna” peste cei cu closetul în curte, tot așa aceste provocări vor veni peste noi ca un „tăvălug”, fără să „bată la ușă”.

Articolul a fost publicat pe $\underline{w w w . b i z l a w y e r . r o ~ s ̦ i ~ i ̂ n ~ r e v i s t a ~ o n l i n e ~ a ~ F a c u l t a ̆ t ̧ i i ~ d e ~ D r e p t, ~}$ AUBD - Forum Juridic nr.3/2020. 